\title{
PARTISIPASI MASYARAKAT TARIQAH PADA PENYELENGGARAAN PENDIDIKAN DI YAYASAN LPMNU TALANG PRIGEN PASURUAN
}

\author{
Akhmad Sirojuddin \\ Fakultas Tarbiyah, Institut Pesantren KH Abdul Chalim Mojokerto \\ Email : akhmadsirojuddin86@gmail.com
}

\begin{abstract}
:
Objective research that will produce research findings that can be used or acted upon by elements related to the investigation. In this case the researchers conducted a regional study in the Tariqah village of Talang Prigen Pasuruan village on matters relating to Jam'iyah's participation in education. In this study the researchers obtained research findings that (1) the participation of the Tariqah community as a facilitator in providing educational services through out-of-school programs, (2) the participation of the Tariqab community as a motivator in the NU Ma'arif education institution in the area, 3) Tariqah community participation as partners in the success of education in the area. This finding is based on the condition of people who have economic, social and educational background. This research hopes to release education in the red region.
\end{abstract}

Keywords : Tariqah community as facilitator, Tariqah community as motivator, Tariqah community as partner.

\section{A. PENDAhULUAN}

Melihat realita yang ada bahwa geografis Indonesia adalah negara yang memiliki 17.500 pulau $^{1}$, melihat data ini tentu akan sangat pengaruh perkembangan masyarakat dalam beberapa aspek seperti aspek ekonomi, sosial, budaya, agama dan semua yang mengikutinya, khusus pada beberapa kasus pemerintah konsen terhadap proses pemerataan yang hingga saat ini memiliki peran penting sehingga otonomi daerah di harapkan mampu sebagai sarana untuk memfasilitasi kebutuhan setiap daerah tertentu sesuai kebutuhan dan kemampuannya, selain beberapa faktor di atas aspek sosial

\footnotetext{
${ }^{1}$ Data Menteri Kemaritiman Nasional Tahun 2015
}

kemasyarakatan juga sangat mempengaruhi aspek pendidikan yang tentunya dari kualitas output lulusannya akan menentukan masa depan bangsa dan negara.

Dengan kondisi masyarakat yang majemuk dengan banyak perbedaan suku, ras, budaya dan bahasa dan agama tentu akan melahirkan banyak perbedaan kualitas Sumber Daya Manusia yang berbeda-beda pula, perbedaan inilah yang juga berimbas pada perbedaan sudut pandang sosial kemasyarakatnya sehingga dengan dinamika ini menjadi salah satu tantangan dan kendala bagi pemerintah untuk dapat melaksanakan program-program pendidikan di setiap penjuru daerah memiliki kualitas yang merata dan baik, sementara Masyarakat yang memiliki 
pemahaman agama yang baik akan menjadi salah satu solusi untuk meningkatkan laju prestasi pendidikan tersebut.

Untuk menuju kesempurnaan ajaran dalam agama terdapat beberapa cara salah satunya dengan Tariqah yang berarti jalan atau metode, pengikut metode ini konsen terhadap segala bentuk ibadah menuju pembersihan hati secara kelompok yang telah di sepakati kemudian menyebar menjadi kekuatan kebaikan (Rub Ad-Da'wah) lewat citra diri dengan berbagai rutinitas yang sudah di jalani ${ }^{2}$. Ali bin Abi Thalib salah satu sahabat nabi pernah bertanya kepada Rasulullah SAW: "Wahai Rasulullah, tunjukkanlah kepadaku jalan (thariqob) terdekat kepada Allah yang paling mudah bagi hamba-hambanya dan yang paling utama bagi Allah!" Rasulullah SAW bersabda: "Kiamat tidak akan terjadi ketika di muka bumi masib terdapat orang yang mengucapkan lafadz "Allab"

Lembaga Pendidikan Ma'arif NU yang ada di desa watuagung dusun talang adalah salah satu lembaga pendidikan di kecamatan prigen yang di kenal berhasil menerapkan pembaharuan prestasi pendidikan khususnya islam melalui pendekatan ajaran Tariqah. Hal ini bisa di lihat dari kegiatan dan beberapa program yang telah di lakukan lembaga ini dengan mencomparasikan dengan rutinitas kegiatan Tariqah baik harian, mingguan hingga bulanan yang ada di kampung dusun talang. Hal lain yang ikut membantu sistem pendidikan di lembaga ini bisa berjalan baik dan maksimal utuk menunjang visi misi lembaga adalah keikut sertaan dan kepedulian masyarakat sekitar yang notabenya mayoritas jamaah Tariqah tersebut untuk meningkatkan potensi sumberdaya manusia, para pendidik, peserta didik, wali murid, para pegawai,

2 Ahmad Muntohar, Pengantar Ilmu Tasawwuf. (Surabaya ; Rosda Karya, 2011) hal. 16 pengembangan program kelembagaan hingga manajemen keuangan dan sarana prasarana.

Berangkat dari beberapa keterangan di atas, peneliti tertarik untuk melakukan penelitian tentang seberapa besar pengaruh masyarakat sekitar yang mayoritas adalah jamaah Tariqah untuk meningkatkan prestasi dan mengembangkan secara keseluruhan potensi di dalam dalam lembaga pendidikan di atas.

\section{B. Kajian Teori}

\section{Definisi Tariqah}

Para ulama menjelaskan arti tariqah, yakni melaksanakan kewajiban dan kesunatan atau keutamaan, meninggalkan larangan, menghindari perbuatan mubah, sangat berhati-hati dalam menjaga diri dari hal-hal yang tidak disenangi Allah dan yang meragukan (syubhat), sebagaimana orang-orang yang mengasingkan diri dari persoalan dunia dengan memperbanyak ibadah sunat pada malam hari, Rutinitas Riyadhah berupa wirit, memperbanyak puasa sunat, dan tidak mengucapkan kata-kata yang tidak beguna dengan memperbanyak memebaca shalawat, istoghosah dan lain sebagainya ${ }^{3}$.

Keterangan lain menyebutkan 'Atb-Thari'qah biya As-sirah almukhtashshah bis-salikin ilallah min qoth'il-manazil wat-taraqqi fil-maqamat. bahwa Tariqah adalah laku tertentu bagi orang-orang yang menempuh jalan kepada Allah, berupa memutusatau bersedia meninggalkan tempat-tempat hunian dan naik ke maqom-maqom atau tempat-tempat yang lebih mulia ${ }^{4}$.

\footnotetext{
${ }^{3} \mathrm{Al}$ Ghazali. Muroqil Ubudiyah fi Syarbi Bidayatil Hidayah. (Cairo : Maktabah Syamilah. Cet 2006) hal. 57

4 Ahmad Al Kamisykhonawi An-Naqsyabandi. Jami'ul Llshul fil Auliya'. cet. 4 terjemah (Jakarta : Mahakarya Press) hal. 77
} 
Habib Lutfi bin Yahya juga menyatakan: Thariqah itu terbagi menjadi dua bagian untuk bisa menempuhnya. Pertama Thariqah Syariah yakni metode mendekat ke jalan Alloh SW'T dengan pendekatan Ilmu Fiqh dan para fuqoba' sebagai sandarannya juga semua aturan dan ketentuan yang ada di dalamnya termasuk juga dari kalangan mubadditsin dan mufassirrin yang telah tersebar luas sebagai salah satu dasar Ilmu pengetahuan dalam Islam. Kedua Thariqah Wushul adalah natijah atau hasil dari Thariqah Syari'ah itu sendiri yang semuanya akan bermuara pada orientasi wala yakni senantiasa tetap menempuh jalan untuk bisa wushul sampai kepada Allah SWT.

Dari pelbagai penjelasan dan pemaparan di atas dapat kita simpulkan bahwa Tarígah adalah sebuah metode atau sistem khusus yang digunakan oleh seseorang untuk menempuh jalan menuju keridla-an Allâh SWT. ${ }^{5}$

Untuk bisa memenuhi kebutuhan ini penting bagi seorang jamaah Tariqah untuk menentukan sebuah metode yang sesuai dengan kemampuan dan keyakinan masingmasing, akan tetapi hampir secara keseluruhan metode dasarTariqab adalah dengan melakukan dzikir. Berdzikir merupakan upaya untuk membersihkan hati dari kotoran hati pengikutnya. Pembersihan dari hal tersebut adalah wajib sebagai upaya dasar sebelum masuk ke dunia wushul, Karena aliran ini meyakini tingkatan kadar keimanan seseorang tergantung pada kadar kebersihan hatinya. Tingkatan kebersihan hatinya tergantung pada kadar kejujurannya. Tingkatan kejujurannya tergantung pada kadar keikhlasannya. Dan tingkatan keikhlasannya tergantung pada kadar keridloannya terhadap apa yang telah diberikan Allah kepadanya. $^{6}$

Oleh karena itu akan lumrah kiranya kegiatan rutinitas Tariqah di atas akan memunculkan perubahan kualitas individu dan juga lingkungannya, semangat perubahan ini akan alamiah menyebar mewarnai dan menjadi solusi dari pelbagai kebutuhan masyarakat. Atsar kebaikan inilah yang di rasakan oleh desa watuagung, desa ini berada di kecamatan prigen kabupaten pasuruan yang sebagian besar masyarakatnya mengikuti Tariqah khususnya Qadiriyah Naqsabandiyah Al-Utsmaniyah. Hal tersebut dapat dilihat dari kebiasaan masyarakat yang mayoritas mata pencaharian nya buruh yang memiliki tingkat ekonomi dan kesadaran pendidikan rendah berangsur-angsur mengalami perubahan pola pikir dalam melihat kebutuhan agama dan peningkatan kesejahteraan hidup khusunya hak dan kewajiban untuk memenuhi kebutuhan pendidikan bagi anakanaknya.

\section{Partisipasi Masyarakat}

Partisipasi masyarakat
adalah wujud $\begin{gathered}\text { kepedulian } \\ \text { masyarakat terhadap sesuatu dan }\end{gathered}$

${ }^{6}$ Menurut Rais 'Am Jam'iyah Ahlit-Thariqah Al-Mu'tabarah An${ }^{5}$ Muhammad Alaydrus. Tariqah Jalan Menuju Khusnul Khotimah. (Nahdliyah, Al-Habib Muhammad Luthfi Bin Yahya, dalam suatu Semarang; Bumi Aksara) hal. 93-95 keterangannya di hari Ahad, 27 Rajab $1425 \mathrm{H}$ atau 12 September 2004 
membentuk perubahan ${ }^{7}$. bahwa partisipasi masyarakat mengacu pada adanya keikutsertaan secara nyata dalam suatu kegiatan, bisa berupa gagasan, kritik membangun, dukungan, dan pelaksanaan pendidikan. Pelibatan partisipasi masyarakat dalam pengelolaan di sekolah memiliki tujuan antara lain :

a. Meningkatkan peran masyarakat untuk ambil bagian dalam perencanaan dan pelaksanaan pendidikan $b$. Membangun rasa memiliki oleh masyarakat terhadap sekolah, rasa tanggung jawab, kemitraan, dan mendorong pengembangan sekolah c. Mengikut sertakan masyarakat dalam meningkatkan mutu dan relevansi dengan menyediakan akses yang lebih besar d. Membantu mengatasi siswa putus sekolah.

Partisipasi masyarakat jika dilakukan dalam hal pengambilan keputusan terhadap sebuah lembaga atau organisasi pendidikan Menurut Abrahamsson (1997:186) bahwa "participation in organization decision making is commonly seen not only a means of reducing the relative power of the executive elite, but also as a way toward a more general democratization of society".

$$
\text { Sedangkan menurut }
$$

French yang dikutip J. Salusu menjelaskan bahwa partisipasi menunjukkan pada suatu proses antara dua atau lebih pihak yang mempengaruhi terhadap yang lainnya dalam membuat rencana,

7 Ahmad nadzir subki. Masyarakat Sosial dan Berbagai Tantangan. Surabaya : Bumi Aksara, 2004. Hal 41 kebijakan dan keputusan ${ }^{8}$. Sesuai dengan kutipan di atas maka keberadaan komite sekolah sebagai bagian dari masyarakat yang berpartisipasi terhadap penyelenggaraan pendidikan di sekolah dapat meliputi kegiatan perencanaan, kebijakan dan keputusan. Komite sekolah yang berasal dari masyarakat dapat memberikan ide-ide dalam perencanaan, kebijakan dan keputusan yang dilakukan oleh pihak penyelenggara pendidikan sekalipun sebagaimana dikatakan diatas bahwa komite sekolah merupakan badan yang terpisah dan mandiri dan tidak menyatu secara struktural dengan penyelenggara pendidikan?.

Dengan demikian makna partisipasi masyarakat di atas merupakan bentuk keterlibatan masyarakat dalam penyelenggaraan pendidikan dengan mengimplementasikan pengetahuan yang dimiliki oleh masyarakat, tenaga dan gagasan atau ide-ide yang muncul dari masyarakat sehingga masyarakat memiliki fungsi antara lain sebagai fasilitator pendidikan, motivator serta menjadi mitra yang bertujuan untuk memberikan kontribusi kepada pihak penyelenggara pendidikan untuk mencapai tujuan pendidikan $^{10}$. Partisipasi masyarakat tersebut meliputi proses, aksi, atau kegiatan yang berupa keikutsertaan nyata semua unsur masyarakat baik yang

\footnotetext{
${ }^{8}$ J. Salusu. Masyarakat Penggerak Perubahan. Jakarta ; Pustaka Bangsa, 1996. Hal 166

${ }^{9}$ Ibid

10 J. Salusu. Masyarakat.......hal. 169
} 
menjadi pengguna sekolah, para stekholder pendidikan, maupun yang peduli terhadap sekolah dalam pengelolaan komponen sekolah $^{11}$.

\section{1) Masyarakat}

Sebagai

\section{Fasilitator}

Partisipasi masyarakat sebagai fasilitator adalah masyarakat yang

berpartisipasi sebagai penyedia, atau membantu penyelenggara pendidikan dalam hal memberikan fasilitas yang dapat digunakan oleh pihak penyelenggara pendidikan dalam proses pembelajaran peserta didik di lingkungan sekolah dan lingkungan sekitar sekolah. Hal tersebut dilakukan masyarakat dengan sukarela, swadaya dan adanya rasa saling percaya antara pihak sekolah dengan masyarakat bahwa masyarakat memiliki pengetahuan, dan keterampilan tertentu yang mungkin tidak dimiliki oleh pihak penyelenggara pendidikan ${ }^{12}$.

2) Masyarakat

Sebagai Motivator

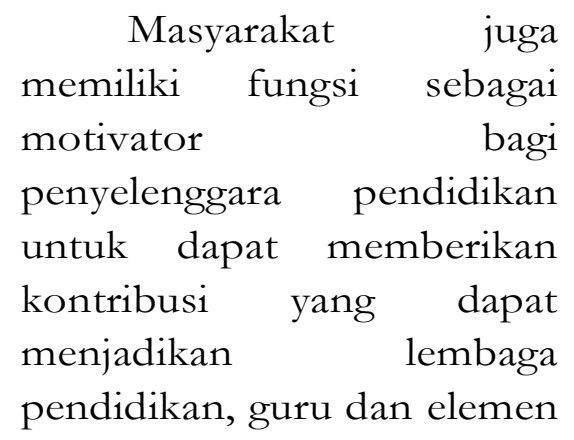

\footnotetext{
11 J. Salusu. Masyarakat.......hal 172

12 Anton Nugroho. Elemen Pendidikan Terhadap Prestasi Belajar Siswa. Jurnal Islamic Studies UIN Malang. 2011. Hal. 63
}

lainnya untuk lebih giat dan bersemangat dalam menjalankan tugas dan tanggungjawabnya sebagai tenaga pendidik. Hal ini akan disebabkan oleh banyak faktor, tapi yang krusial bahwa masyarakat akan menjadi motivator alamiah karena tabiat sosial, budaya, pengetahuan dan kepribadian yang pluralistik mengakibatkan presurre sosial serta profesional akan meningkat ${ }^{13}$.

\section{3) Masyarakat Sebagai Mitra}

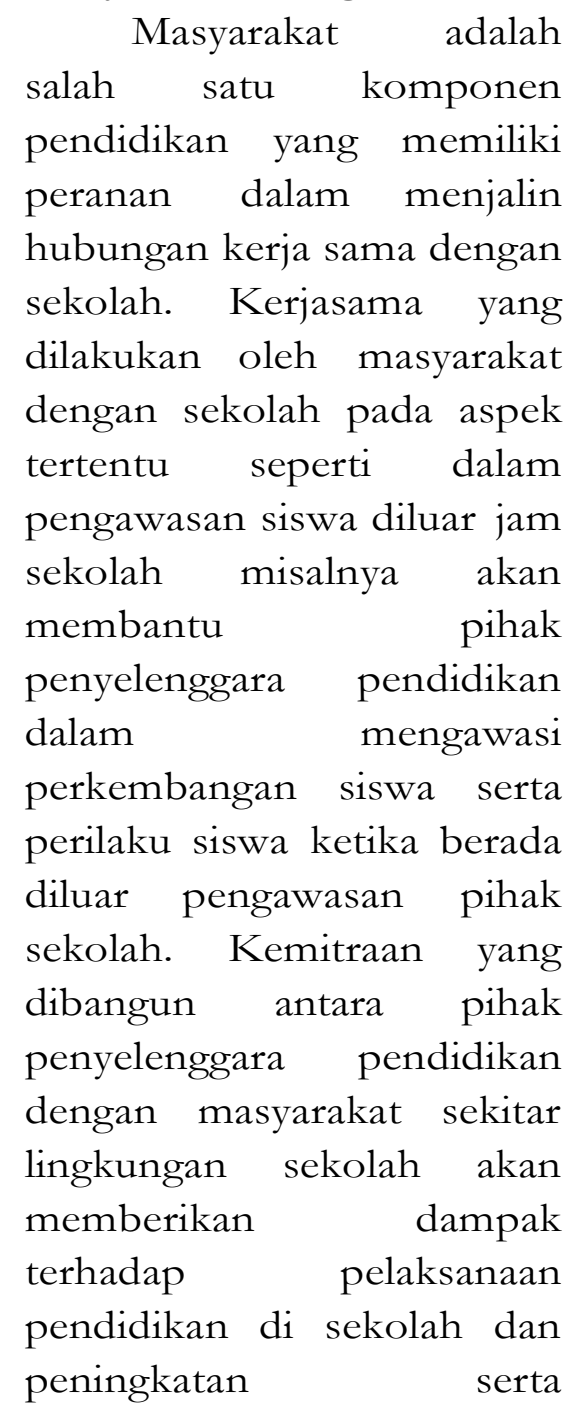

\footnotetext{
13 Abdul Jabbar. Pendidikan Indonesia (Harapan dan Tantangan). Jakarta ; Pustaka Karya, 2004. Hal. 112
} 
pengembangan prestasi baik di lembaga pendidikan tersebut maupun SDM yang ada di dalamnya secara keseluruhan ${ }^{14}$.

\section{Metode Penelitian}

Penelitian ini merupakan penelitian lapangan (field research) dan termasuk dalam penelitian kualitatif, maksud dari kualitatif adalah penelitian yang bermaksud untuk memahami fenomena tentang apa yang dialami oleh subjek penelitian, misalnya tentang perilaku, persepsi, motivasi, tindakan dan lain-lain, secara holistik, dan dengan cara deskripsi dalam bentuk kata-kata dan bahasa, pada suatu konteks khusus yang alamiah dan dengan memanfaatkan berbagai metode alamiah. ${ }^{15}$ Metode ini digunakan untuk beberapa kondisi obyek penelitian secara alamiah, dimana peneliti sebagai instrumen kunci, teknik pengumpulan data menggunakan triangulasi, analisis data bersifat induktif yang hasil penelitian kualitatif lebih menekankan pada makna dari pada generalisasi. ${ }^{16}$

Adapun pendekatan yang dilakukan berupa pendekatan deskriptif, melalui pendekatan ini, peneliti akan menyajikan hasil penelitian berupa kutipan-kutipan data untuk memberikan gambaran penyajian laporan penelitian. Data diambil dari naskah wawancara, catatan lapangan, dokumen pribadi, catatan penting dan dokumen resmi lainnya. ${ }^{17}$ Adapun Jenis penelitian yang digunakan peneliti yaitu penelitian kualitatif deskriptif, maka penelitian ini akan mendeskripsikan beberapa peran dan partisipasi masyarakat Tariqah terhadap penyelenggaraan pendidikan di LPMNU Talang Prigen Pasuruan.

Subjek penelitian berarti subjek dimana data diperoleh baik berupa orang, respon, benda, gerak atau proses sesuatu. ${ }^{18}$ Hal ini di asumsikan subjek yang dipilih dapat mewakili data dari penelitian yang dilakukan, atau informan. Perolehan data dari informan, dalam penelitian ini penulis menggunakan Purposive Sampling, yaitu orang-orang terpilih yang akan diberi pertanyaan dan pernyataan menurut ciriciri spesifik yang dimiliki sampel tersebut. ${ }^{19}$ Informan yang dipilih merupakan orang yang mengetahui dan memahami data yang diperlukan dalam penelitian. Adapun subjek penelitian dalam penelitian ini adalah Lembaga Pendidikan Ma'arif NU dan masyarakat Talang Prigen Pasuruan.

Sumber data yang digunakan yaitu sumber data primer dan sumber data sekunder. Sumber data primer diperoleh dari penelitian langsung di lokasi penelitian dan informasi yang didapatkan dari subjek penelitian. Sedangkan data sekunder diperoleh dari karya tulis, buku, artikel, jurnal ataupun sumber lainnya yang sesuai dengan kebutuhan penelitian.

Sementara peneliti sendiri berposisi sekaligus sebagai instrumen penelitian atau sebagai alat pengumpul data. Peneliti sekaligus sebagai perencana, pelaksana pengumpulan data, analisis data, dan pada akhirnya menjadi pelapor penelitian. $^{20}$ Peneliti menjadi segalanya dari keseluruhan proses penelitian. Adapun teknik yang digunakan penulis dalam pengumpulan data, yaitu observasi, wawancara dan dokumentasi.

\footnotetext{
14 Ruhatikno. Sosiologi Pendidikan. Jogjakarta ; Mutiara Bangsa, 2001. Hal. 54

${ }^{15}$ Lexy J. Moleong Metodologi Penelitian Kualitatif Edisi Revisi, (Bandung: PT Remaja Rosdakarya, 2012), hlm. 6.

${ }^{16}$ Sugiyono, Metode Penelitian Kuantitatif, Kualitatif, dan

Kombinasi (Mixed Methods), (Bandung: Alfabeta, 2013), hlm. 13

${ }^{17}$ Lexy J. Moleong, Metodologi Penelitian ..., hlm. 17.
}

\footnotetext{
${ }^{18}$ Suharsimi Arikunto, Prosedur Penelitian, Suatu Pendekatan Praktek

(Jakarta: Rieneka Cipta, 1998), hlm. 402.

${ }^{19}$ S. Nasution, Metode Research: Penelitian Ilmiah, (Jakarta: Bumi

Aksara, 1996), hlm. 8.

${ }^{20}$ Lexy J. Moleong, Metodologi Penelitian ..., hlm. 168.
} 
Teknik analisis data yaitu proses penyusunan data agar dapat di terjemahkan kemudian di sajikan dalam bentuk tulisan, kata-kata atau lisan. Proses ini dilakukan selama proses penelitian di lapangan berlangsung dan setelah selesai pengumpulan data lapangan. Hasil yang diperoleh selama di lapangan di analisis kembali sehingga data yang diperoleh valid dan dapat dipertanggungjawabkan. Analisis data kualitatif yang dilakukan merujuk pada pandangan Miles dan Huberman yaitu melalui proses data reduksi, data display (penyajian data), dan conclution drawing (verification). ${ }^{21}$ Reduksi data berarti merangkum data berdasar hal-hal inti atau pokok. Display data berarti data inti dideskripsikan secara naratif dan sistematis. Verifikasi data berarti mencari pola, bentuk, tema, hubungan, persamaan, perbedaan, dan faktor yang memengaruhi sehingga didapatkan suatu kesimpulan utuh, menyeluruh dan akurat.

Untuk mengujia keabsahan data dengan uji kredibilitas yaitu menggunakan triangulasi. ${ }^{22}$ Triangulasi adalah teknik pemeriksaan keabsahan data yang memanfaatkan sesuatu yang lain di luar data itu untuk keperluan pengecekan atau sebagai pembanding terhadap data itu. Triangulasi dapat merupakan triangulasi sumber, metode, penyidik, dan teori. ${ }^{23}$ Dalam hal ini peneliti melakukan triangulasi terhadap sumber di mana ada pemeriksaan kembali pada hasil yang diperoleh dari beberapa subjek data atau informan, kemudian triangulasi metode dengan cara memeriksa kembali hasil yang diperoleh peneliti melalui pengamatan, wawancara, dan dokumentasi.

\footnotetext{
${ }^{21}$ Sugiyono, Metode Penelitian Pendidikan (Pendekatan Kuantitatif, Kualitatif dan R\&D), (Bandung: Alfabeta, 2015), hlm. 334.

22 Ibid., hlm 336.

${ }^{23}$ Lexy J. Moleong, Metodologi Penelitian ..., hlm. 330.
}

\section{D.HASIL PENELITIAN DAN PEMBAHASAN \\ Pembahasan \\ temuan \\ penelitian secara deskriptif ditampilkan oleh peneliti sebagai mana berikut ini :}

\section{Partisipasi \\ Program}

\section{Masyarakat}

Lembaga Pendidikan

Ma'arif NU Talang memiliki sedikit perbedaan dengan lembaga pendidikan pada umumnya. Keberadaan siswa yang hampir 30\% adalah anak dari keluarga tidak mampu membuat kepedulian masyarakat sekitar sebagai penyedia sarana yang dapat membantu proses belajar para siswa khususnya bagi anak yang tidak mampu. Apabila melihat pada teori atau konsep fasilitas yang dikemukakan oleh para ahli seperti yang dikatakan James A. Thomkins (1996:2) bahwa "facilities planning determines bow an activity tangible fixed assets best support achieving the activity." Maksud dari konsep ini menjelaskan bahwa sebuah perencanaan fasilitas akan dapat menentukan ketercapaian sebuah kegiatan.

\section{a. Dompet Jariyah}

LPMNU sebagai

lembaga pendidikan tentunya memiliki target pada setiap aktivitasnya, target terdekat adalah memberikan layanan dan hak yang sama bagi seluruh peserta didik untuk menciptakan lingkungan yang kompetitif dan berprestasi. Dalam proses belajar setiap siswa membutuhkan sarana berupa perlengkapan belajar, 
seragam, buku pedoman

belajar semacam LKS dan pembayaran SPP perbulannya. Masyarakat Talang sebagai bagian dari elemen pendidikan membuat program "Dompet Jariyah" bekerjasama dengan Jam'iyah Tariqah setempat dan berkoordinasi dengan tiap RT/RW dan kepala dusun setempat yang diharapkan masyarakat bisa ikut membantu kebutuhan dan layanan bagi peserta didik yang tidak mampu.

\section{b. Bank Sampah}

Temuan lainnya yang didapat oleh peneliti di lokasi penelitian adalah masyarakat yang berpartisipasi pada program yang dilakukan oleh sekolah yaitu Bank sampah. Pada program ini masyarakat berpartisipasi sebagai penyedia bahan-bahan yang akan di kumpulkan menjadi biji plastik atau non palstik dan kemudian di jual dengan harga yang lebih mahal, Masyarakat juga bersinergi untuk tidak membuang sisa-sisa limbah rumah tangga seperti potongan sayuran yang sudah tidak dipakai dan bahan-bahan lainnya untuk di jadikan pupuk, di hari tertentu selama satu minggu anak-anak membawa limbah rumah tangga tadi untuk dibawa ke sekolah dan dipandu oleh seorang guru bersama-sama mengolah limbah rumah tangga tersebut menjadi pupuk kompos, hal ini bertujuan untuk mengurangi volume sampah di desa, menghindari pelbagai resiko penyakit dan hasil limbah kompos tersebut di gunakan untuk sarana penghijaunan area sekolah yang di canangkan kepala sekolah dan di bagikan untuk warga di sekitar sekolah dan masyarakat yang membutuhkan.

\section{c. Jumat Bersih}

Selain itu masyarakat yang memiliki fungsi sebagai fasilitator juga dapat dilihat dari sumbangsih yang sangat besar pada program 'Jum'at Bersib" yang di gagas oleh yayasan dan jam’iyah Tariqah, di hari itu masyarakat umum dan semua elemen lembaga bersama-sama membersihkan lingkungan dan tempat ibadah yang bertujuan agar sekolah dan lingkungan desa lebih terlihat sejuk dan bersih sehingga secara tidak langsung kegiatan ini juga akan membangun dan mempererat kembali sistem komunikasi dan jiwa sosial yang baik, dengan begitu kepercayaan masyarakat terhadap lembaga pendidikan khususnya di LPMNU akan terus meningkat.

Dalam penelitian ini peneliti menganggap bahwa masyarakat dusun talang yang dianggap sebagai masyarakat arogan dan tergolong memiliki latar belakang pendidikan yang rendah, kesadaran sosial yang buruk mulai memiliki rasa tanggung jawab terhadap pendidikan yang ada di lingkungan tempat mereka tinggal. $\mathrm{Hal}$ ini di sebabkan karena 
pengaruh rutinitas Tariqah yang sangat kental di desa ini mengakibatkan budaya sosial masyarakat berubah secara signifikan. Hal ini senada dengan Edward Mirage bahwa rutinitas yang tersistem dan terjadi secara kontinue dengan waktu yang lama akan mempengaruhi mindsite dan perilaku sosial seseorang, tingkat pengaruh ini yang jadi dasar perlakuan sosial setempat melakukan perubahan pada pribadi dan memunculkan kesadaran akan kewajiban dan hak di lingungan sekitarnya. Teori pembelajaran pembiasaan (Habbit Forming) juga menjadikan ini sebagai metode dengan penanaman kebiasaan dengan pengulangan berupa penglihatan, pendengaran dan pengucapan yang terjadi berulang kali dan di lakukan dalam waktu yang lama akan membuat kebiasaan baru pada diri peserta didik ${ }^{24}$

\section{Partisipasi Jama'ah Tariqah}

Pembahasan temuan penelitian yang selanjutnya adalah temuan penelitian yang menunjukkan bahwa masyarakat Talang yang notabene adalah mayoritas jama'ab Tariqah memiliki partisipasi sebagai motivator pada penyelenggaraan pendidikan di lembaga pendidikan Ma'arif NU tempat mereka tinggal. Jika melihat kepentingan prinsip Tariqah maka sudah jelas bahwa motivasi Jam'iyah ini adalah pembersihan hati dan pemurnian ajaran melalui Riyadhah Batiniyah lewat rutinitas indvidu maupun kelompok yang tersistem dan terstruktur dengan baik akan memunculkan sebuah nilai yang mendorong dirinya untuk bersinergi dengan lingkungannya.

Motivasi tersebut di gambarkan melalui rutinitas jam'iyyah berupa wirid Jama'i, pengajian, Istighosah, Manaqiban, Khususi yang dilakukan setiap minggu pada setiap masjid, musholla, RT dan RW. Kegiatan ini terbuka bagi simpatisan yang ingin mengikuti kegiatan rutinan ini selain dari jama'ah Tariqah itu sendiri untuk masyarakat desa Talang khususnya. Pada beberapa waktu tertentu jam'iyah dan rutinitas ini dihadirkan ke sekolah atas undangan lembaga dan yayasan, kegiatan ini rutin terjadi minimal 2 bulan sekali sehingga terjadi interaksi dan komunikasi yang intens terhadap semua elemen lembaga pendidikan kususunya orang tua murid untuk memenuhi peningkatan kualitas pendidikan melalui pemahaman keagamaan yang baik dan perbaikan diri sehingga secara tidak langsung akan membantu proses penanaman nilai pendidikan melalui peningkatan layanan, hak dan kewajiban orang tua untuk kebutuhan lingkungan sosial, budaya keluarga dan anakanaknya.

\footnotetext{
${ }^{24}$ Hery Noer Ali. Teori Pembelajaran (Habbit Forming). Jakarta ;
} 
Temuan lain yang berkaitan dengan partisipasi jamaah Tariqah sebagai motivator pada penyelenggaraan pendidikan di LPMNU Talang adalah perhatian yang di lakukan oleh ketua Tariqah (baca:imam khususi) melalui komite sekolah yang berperan aktif sebagai fasilitator dan motivator untuk menunjang kebutuhan masyarakat kepada guru dan lembaga pendidikan terkait, melalui layanan informasi sesuai dengan kebutuhan dan capaian pendidikan. Dalam hal ini tindakan yang dilakukan oleh ketua jama'ah kepada para guru dan pihak sekolah secara umum merupakan bentuk motivasi yang di lakukan apabila di interpretasikan melalui konsep yang dikemukakan oleh Hikmat (2009:272) bahwa motivasi adalah "dorongan atau rangsangan yang diberikan kepada seseorang agar memiliki kemauan untuk bertindak melakukan perubahan".

\section{Kemitraan (Patnership)}

Pada bagian ini akan dibahas temuan peneliti yang membuktikan tentang keberadaan partisipasi masyarakat secara keseluruhan sebagai mitra pendidikan. Hubungan yang terjalin antara sesama masyarakat di wilayah ini tidaklah diragukan kebersamaan dan kekompakannya. Salah satu faktor penyebabnya adalah budaya sosial dan rutinitas yang sinergi antara kegiatan masyarakat awam dan kegiatan rutinitas jama'ah tariqah.
Soekidjo Notoatmodjo mengemukakan bahwa kemitraan adalah suatu kerjasama formal antara individu-individu, kelompok-kelompok, atau organisasi-organisasi untuk mencapai suatu tugas atau tujuan tertentu. Pada konteks kemitraan yang disebutkan oleh Soekidjo Notoatmodjo memberikan persepsi bahwa kemitraan akan terjadi jika terdapat dua orang atau dua kelompok, organisasi ataupun komunitas yang melakukan kerja sama dalam mewujudkan tujuantujuan tertentu ${ }^{25}$.

Salah satu bukti sinergitas kegiatan di atas di gambarkan melalui beberapa kegiatan misal rutinan tariqah setiap hari ahad yang bergilir ke semua rumah di desa tersebut, pada tiap hari kamis di adakan rutinan istighosah kubro bertempat di masjid desa. Sedangkan hubungan antara masyarakat Tariqah dengan pihak penyelenggara pendidikan di daerah tersebut dalam hal ini adalah LPMNU Talang Prigen, Tidak sedikit orang-orang yang termasuk dalam elemen-elemen yang ada di lembaga pendidikan tersebut merupakan warga masyarakat dan alumni lembaga tersebut. Bahkan Imam Khususi (Baca ; Pemimpin Tariqah Wilayah) merupakan salah satu pendiri yayasan LPMNU tersebut, selain itu beberapa pemuka agama, kepala desa, dewan guru di lembaga tersebut juga termsuk bagian dari Jama'ah Tariqah ini.

25 Soekidjo Notoatmodjo. Urgensi Kemitraan Untuk Keberhasilan Pendidikan. Jogjakarta ; Yahna Press, 2003. Hal. 100 
Beberapa penjelasan di atas menjadi salah satu bukti dan sebab terbentuknya kemitraan antara pihak masyarakat awam, jamaah tariqah dan lembaga pendidikan yang ada di lingkungan tersebut untuk mencapai tujuan tertentu, ketentuan yang di maksud adalah tujuan perbaikan dan pengembangan diri untuk kebutuhan individu dan masyarakat melalui :

(1) Adanya keinginan antar individu atau antar kelompok untuk bekerja sama, (2) Adanya bentuk kerja sama yang jelas (formal dan nonformal) antara individu atau antar kelompok (3) Adanya sesuatu yang dituju sehingga kemitraan memiliki tujuan yang jelas.

Dalam lingkup hubungan masyarakat dan jama'ah Tariqah di desa talang kerjasama seperti ini lebih dominan terjadi karena adanya unsur timbal balik antara warga dengan pihak penyelenggara pendidikan sebagaimana yang diungkapkan oleh salah seorang warga bahwa masyarakat kebanyakan menganggap bahwa masyarakat sekitar yang mayoritas sebagai anggota dan jama'ah Tariqah dan lembaga pendidikan di bawah naungan LPMNU Talang sangat memahami kondisi masyarakatnya yang tergolong awam dan tidak berkecukupan. Kendati demikian pihak sekolah tidak pernah menganggap masyarakat dengan sebelah mata, hal itu yang menjadikan masyarakat secara umum tidak segan dalam mengikuti dan membantu lembaga pendidikan untuk keberhasilan programprogramnya lembaga pendidikan tersebut.

\begin{tabular}{lcr}
\multicolumn{3}{c}{ Dengan demikian peneliti } \\
dalam membahas temuan- \\
temuan
\end{tabular}
menghubungkan konsep-konsep ataupun pendapat para ahli yang sesuai dengan fokus dan subfokus yang bertujuan agar temuan-temuan penelitian tersebut oleh peneliti dapat di verifikasi dan menjadi temuan yang proposisi. Adapun temuan proposisi tersebut adalah segala bentuk temuan penelitian yang berkaitan dengan subfokus yang dalam pembahasan ini adalah partisipasi masyarakat Tariqah sebagai mitra pada penyelenggaraan pendidikan di desa Talang, yaitu kerjasama atau partnership yang terjalin antara masyarakat Tariqah dengan pihak penyelenggara pendidikan adalah hal yang menunjukkan pada keunikan yang terdapat di lokasi penelitian, karena hal-hal yang terjadi di lokasi penelitian yang berkenaan dengan kemitraan kedua elemen pendidikan jarang terjadi apabila kita melihat kondisi wilayah Talang yang sebelumnya masuk kategori merah, marginal dan didominasi oleh kriminalisasi yang masyarakatnya yang memiliki taraf kehidupan ekonomi dan pendidikan yang rendah.

Maka peneliti menetapkan bahwa keunikan 
yang terjadi, ataupun peristiwa yang berlangsung dan didapat melalui pengamatan langsung dan wawancara dengan unit analisis merupakan temuan penelitian yang menjadi penyebab munculnya subfokus dalam penelitian ini.

\section{E. KESIMPULAN}

Masyarakat secara umum dan jama'ah Tariqah desa talang dalam menyikapi hal-hal yang berkaitan dengan peningkatan pendidikan khususnyaa tantangan starta sosial dan ekonomi yang rendah di lakukan dengan pendekatan kultural keagamaan melalui rutinitas pembiasaan hingga menjadi kebiasaan perubahan sikap individu, sosial dan budaya masyarakatnya, sebab kita dapat melihat peran serta masyarakat talang yang mayoritas jama'ah tariqah memiliki dampak yang jelas dalam memberikan pengaruh terhadap pelaksanaan dan keberhasilan program-program yang adadi LPMNU Talang.

Partisipasi masyarakat dan jama'ah Tariqah untuk membantu lembaga pendidikan sebagai penyedia sarana dan layanan pendidikan merupakan bagian dari tolak ukur sebagai motivator meskipun kondisi masyarakat yang sebelumnya sangat awam, bagian dari red zone karena kriminalisasi dan kebiasaan buruk sosial masyarakat sebelumnya namun masih dapat membantu dan mendukung keberlangsungan kebutuhan masyarakat terhadap peningkatan pendidikan di LPMNU Talang.
Bentuk lain yang merupakan partisipasi masyarakat Tariqah terhadap penyelenggaraan pendidikan di desa Talang adalah partisipasi masyarakat tariqah yang bertindak sebagai mitra melalui pendekatan kemitraan individu, golongan (masyarakat) atau organisasi struktural lembaga pendidikan untuk memenuhi keberhasilan program pendidikan di lembaga pendidikan tersebut. 



\section{DAFTAR RUJUKAN}

Alba, Cecep. 2014. Tasawuf Dan

Tarekat Dimensi Esoteris Ajaran Islam. (Bandung ; Rosdakarya)

Al-Kamisykhonawi, Ahmad. AnNaqsyabandi. 1997. Jami'ul Llshul fil Auliya' . cet. 4 terjemah Jakarta : Mahakarya Press

Al Ghazali. Muroqil Ubudiyah fi Syarbi Bidayatil Hidayah. 2006 Cairo : Maktabah Syamilah. Cet VI

Arikunto, Arikunto. 1998. Prosedur Penelitian, Suatu Pendekatan Praktek Jakarta: Rieneka Cipta

Bent, Abrahamsson. 1997 Bureaucracy or Participation The Logic of Organization, London: Sage Publication Ltd.

Jabbar, Abdul. 2004. Pendidikan Indonesia (Harapan dan Tantangan). Jakarta ;

Pustaka Karya.

J. Moleong, Lexy. 2012. Metodologi Penelitian Kualitatif Edisi Revisi. Bandung: PT Remaja Rosdakarya

Kreitner and Kinicki. 2008. Organizational Behavior. singapore: McGraw-hill.

Karisma, Nur. 2010. Sosial Masyarakat Agamis. ( Surabaya : Cipta Cendekia)

LePine Collquitt \& Wesson. 2008. Organizational Behavior, singapore: McGraw-Hill.

Maulidiyah, Zahrun. 2012. Tafsir Tasawwuf. (Jogjakarta ; Karina Press )

Media perempuan. 2005 : Media Informasi Komunikasi Kesetaraan dan Keadilan Geneder. edisi no.6
Media Perempuan. 2005. Media Informasi Komunikasi Kesetaraan dan Keadilan Gender. Edisi no.2.

Mulyasa E. 2004. Menjadi Kepala Sekolah Profesional, Bandung: Remaja Rosdakarya

Muntohar, Ahmad. 2011. Pengantar Ilmu Tasawwuf. Surabaya ; Rosda Karya

Nadzir Subki, Ahmad. 2004. Masyarakat Sosial dan Berbagai Tantangan. Surabaya : Bumi Aksara.

Nugroho, Anton. 2011. Elemen Pendidikan Terhadap Prestasi Belajar Siswa. Jurnal Islamic Studies UIN Malang. Cet. I

Notoatmodjo Soekidjo. 2003. Pendidikan dan Prilaku Kesehatan. Rineka Cipta, Jakarta.

Nasution, S. 1996. Metode Research: Penelitian Ilmiah. Jakarta: Bumi Aksara. Noer Ali, Hery. 2003. Teori

Pembelajaran (Habbit Forming). Jakarta ; Pustaka Cendekia.

Ruhatikno. 2011. Sosiologi Pendidikan. Jogjakarta ; Mutiara Bangsa

Ramly, Najmuddin. 2005 Membangun Pendidikan yang Memberdayakan dan Mencerabkan, Jakarta: Grafindo Khazanah Ilmu.

Robbins, Stephen P. \& Thimoty A. Judge. 2009. Organizational behavior, Singapore: $13 \mathrm{fth}$ ed. Person international ed.

Sudarmawan, Danim. 2004. Motivasi Kepemimpinan dan Efektivitas Kelompok, Jakarta: Rineka Cipta.

Salusu J. 1996. Pengambilan Keputusan Strategik Untuk Organisasi Publik dan Organisasi Non Profit, Jakarta: Grasindo. 
Sugiyono, Metode Penelitian

Kuantitatif, Kualitatif, dan

Kombinasi (Mixed

Methods). Bandung:

Alfabeta.

Sugiyono. 2015. Metode Penelitian

Pendidikan (Pendekatan

Kuantitatif, Kualitatif dan

R\&D) Bandung: Alfabeta
Tompkins, A. James. 1996. Facilities Planning. Singapore: John Wiley \& Sons INC,

Hikmat. 2009. Manajemen

Pendidikan, Bandung: CV Pustaka Setia

Hirsanuddin. 2008. Hukum perbankan Syariah di Indonesia ; Pembiayaan Bisnis Dengan Prinsip Kemitraan, Yogyakarta : Genta Press. 